\title{
HIPERGLIKEMIA PADAANAK
}

\author{
Diah Hermayanti ${ }^{1}$, Erlin Nursiloningrum ${ }^{2}$ \\ ${ }^{1}$ Patologi klinik di Fak. Kedokteran, Univ. Muhammadiyah Malang; RSI Aisyiah Malang \\ ${ }^{2}$ Patologi klinik di RSI Aisyiah Malang
}

Email : diahhermayanti_umm@yahoo.com

\begin{abstract}
ABSTRAK
\section{Pendahuluan}

Diabetes mellitus (DM) merupakan penyakit metabolik ditandai oleh hiperglikemia yang disebabkan berkurangnya produksi atau kerja insulin. DM dapat menyerang anak-anak. Kami melaporkan kasus hiperglikemia pada anak berusia 9 tahun dengan kadar C-peptida dalam batas normal.
\end{abstract}

\section{Kasus}

Anak perempuanberusia 9 tahun, dibawa ke rumah sakit dikeluhkan lemah badan selama satu minggu. Pasien juga dikeluhkan sering kencing terutama di malam hari selama sebulan dan bekas kencing dirubung oleh semut. Pemeriksaan fisik dalam batas normal. Pemeriksaan laboratorium hari pertama : hemoglobin 14,8 g/dl, leukosit $9.860 \mathrm{sel} / \mathrm{ul}$, trombosit $297.000 \mathrm{sel} / \mathrm{ul}$, gula darah acak $328 \mathrm{mg} / \mathrm{dl}$. Pemeriksaan hari kedua : gula darah puasa $274 \mathrm{mg} / \mathrm{dl}$, gula darah 2 jam post prandial $370 \mathrm{mg} / \mathrm{dl}$, dan glukosuria. Pemeriksaan C-Peptida 2,74 ng/ml (normal 1,1 - 4,4 ng/ml)

\section{Pembahasan}

Pada pasien anak ini ditemukan gejala khas diabetes yaitu fatigue dan poliuri. Pada pemeriksaan laboratorium didapatkan hiperglikemia. Sesuai dengan pedoman dari PERKENI pasien ini didiagnosis sebagai DM, yaitu tipe-1, dengan diferential diagnosis Maturity onset diabetes of the young (MODY) mengingat kadar C-peptida dalam batas normal. DM tipe 1 disebabkan oleh karena kerusakan sel beta pankreas akibat adanya autoantibodi terhadap pankreas. Sedangkan MODY disebabkan oleh mutasi genetik pada sel â pankreas sehingga terjadi inefektifitas produksi atau gangguan pelepasan insulin. Pemeriksaan tambahan seperti deteksi antibodi sel islet disarankan untuk menetapkan diagnosis DM tipe 1, dan pemeriksaan genetik untuk mendeteksi terjadinya mutasi sel â pankreas.

\section{Simpulan}

Diagnosis Type-1 Diabetes mellitu, dengan diagnosis banding Maturity onset diabetes of the young(MODY)

Kata Kunci: hiperglikemia anak, C-peptida, Diabetes mellitus tipe-1, MODY 


\section{ABSTRACT}

\section{Introduction}

Diabetes mellitus (DM) is a metabolic disease characterized by hyperglycemia resulting from reduced insulin production, insulin action, or both. DM can attack children. This case reports a nine years old girlwith hyperglycemia and normal levels of C-peptide.

\section{Case}

A 9-year-old girl presented to the hospital with fatigue for one week. She also complained of frequent urination, especially at night for a month and the former urine were meshed by ants. Physical examination were within normal limits. First day laboratory examination data: haemoglobin $14,8 \mathrm{~g} / \mathrm{dl}$, leukocytes $9.860 \mathrm{cells} / \mathrm{ul}$, platelets $297.000 \mathrm{cells} / \mathrm{ul}$, random blood glucose $328 \mathrm{mg} / \mathrm{dl}$. Second day examination: fasting blood glucose $274 \mathrm{mg} / \mathrm{dl}$, blood glucose 2 hours post prandial 370 $\mathrm{mg} / \mathrm{dl}$, and glucosuria. Examination of C-Peptide was 2,74 ng/ml (normal 1,1 - 4,4 ng/ml)

\section{Discussion}

We found typical symptoms of diabetes in this patient which are fatigue and polyuria. Laboratory examination found hyperglycemia. In accordance with the guidelines of PERKENI, she can be diagnosed as a type-1 DMwith differential diagnostic was Maturity onset diabetes of the young (MODY), considering the levels of C-peptide within normal limits.The pathophysiology in diabetes type 1 is a destruction of beta cells in the pancreas by autoantibodies. MODY is caused by a genetic mutation in pancreatic â cells resulting in production ineffectiveness or release impairment of insulin. Additional examination such as detection of islet cell antibodies is suggested to diagnose type $1 \mathrm{DM}$, and genetic testing to determine the occurrence of pancreatic â cell mutations.

\section{Conclussion}

The patient was diagnosedasType-1 Diabetes mellitus, with the differential diagnosis was Maturity onset diabetes of the young (MODY).

Keywords: hyperglycemia in children, C-peptide, Type-1 Diabetes mellitus MODY

\section{PENDAHULUAN}

Diabetes mellitus (DM) merupakan penyakit metabolik ditandai oleh hiperglikemia yang disebabkan berkurangnya produksi atau kerja insulin ${ }^{1}$. DM dapat menyerang anak-anak. Pada anak-anak yang tersering adalah DM -1 (insulindependent), danMaturity onset diabetes of the young (MODY) (noninsulin-dependent)(Gardner DSL, 2012).

DM tipe 1 mewakili sekitar $10 \%$ dari semua kasus diabetes, menyerang sekitar 20 juta orang di seluruh dunia. Meskipun DM tipe 1 menyerang semua kelompok umur, mayoritas individu didiagnosis di sekitar usia 4 sampai 5 tahun, atau di usia remaja dan dewasa awal. Insiden diabetes tipe 1 meningkat. Di seluruh Eropa, ratarata peningkatan tahunan dalam kejadian anak di bawah 15 tahun adalah 3,4\%, dan kejadian paling tinggi pada anak di bawah usia 5 tahun (Orougwu JC,2013).

DM tipe 1 disebabkan karena hilangnya kemampuan mensekresi insulin akibat kerusakan autoimun selektif terhadap sel beta pankreas. Tipe ini merupakan tipe diabetes poligenik yang berhubungan dengan banyak gen. Antibodi terhadap plasma sitokrom sel islet, dekarboksilase asam glutamat, dan tirosin fosfatase-seperti protein (IA2 atau IA-2 b), yang muncul sebelum onset klinis diabetes, merupakan penanda yang baik adanya proses autoimun (Imagawa A, 2000).

Pada kasus yang sangat jarang, diabetes dapat terjadi karena mutasi hanya dari satu jenis gen, disebut diabetes monogenik. Diabetes monogenik dapat diwariskan secara dominan ataupun resesif, atau muncul spontan akibat mutasi 
de novo. Pada anak-anak, mutasi biasanya terjadi pada gen yang meregulasi fungsi sel beta pankreas; pada kasus jarang, mutasi juga dapat menyebabkan resistensi insulin berat. Hingga saat ini, sudah ditemukan 40 jenis subtipe diabetes monogenik, masing-masing memiliki fenotipe tersendiri dengan pola pewarisan spesifik. Prevalensi diabetes monogenik anak adalah $1-4 \%$ dari seluruh kasus diabetes pediatrik (Tengguna L, 2012). Diabetes familial disebut juga sebagai maturity onset diabetes of the young (MODY) (Tengguna L, 2012).

\section{KASUS}

Seorang anak perempuan berusia 9 tahun

\section{Keluhan Utama :}

Badan lemah

\section{Anamnesis :}

Keluhan lemah badan selama satu minggu. Pasien juga sering kencing terutama di malam hari selama sebulan terakhir dan bekas kencing dirubung oleh semut. Sebelum ke RS ini, periksa di puskesmas dan cek gula darah acak hasilnya $500 \mathrm{mg} / \mathrm{dl}$

\section{Riwayat Penyakit Dahulu}

DM (-), kejang (-), alergi (-), asma (-)

\section{Riwayat Penyakit Keluarga}

Kakek : DM (+), orang tua : DM disangkal

\section{Pemeriksaan Fisik}

Kesadaran compos mentis, tampak lemah, HR: 100x/ $\mathrm{mnt}$, RR $20 \mathrm{x} / \mathrm{mnt}$, suhu: $36,5^{\circ} \mathrm{C}$, akral hangat, TB : $124 \mathrm{~cm}, \mathrm{BB}: 26 \mathrm{~kg}$.

$\mathrm{K} / \mathrm{L}$ : anemia -/-, ikterik -/-, pupil bulat isokor, pembesaran KGB (-)

Thorax : Pulmo simetris, rh -/-, wh -/-, Cor S1S2 tunggal

Abdomen : BU (+) normal, soefl, nyeri tekan (-) Ekstremitas : anemia -/-, oedema -/-

Pemeriksaan Penunjang

Tabel 1. Pemeriksaan Laboratorium

\begin{tabular}{|c|c|c|c|c|}
\hline $\begin{array}{c}\text { Parameter } \\
\text { I } \\
\text { Hemoglobin }\end{array}$ & $\mathbf{1 8 / 8 / 2 0 1 7}$ & $\mathbf{1 9 / 8 / 2 0 1 7}$ & $\mathbf{2 1 / 8 / 2 0 1 7}$ & Nilai rujukan \\
\hline Lekosit & 9.860 & & & $10,8-15,6 \mathrm{gr} / \mathrm{dL}$ \\
\hline Trombosit & 297.000 & & & $4.500-13.500 / \mathrm{uL}$ \\
\hline Hematokrit & 42,2 & & & $184.000-488.000 / \mathrm{uL}$ \\
\hline LED & 19 & & & $33-45 \%$ \\
\hline Hitung jenis & $2 / 0 / 0 / 37 / 51 /$ & & & $25-60 / 25-50 / 1-6 \%$ \\
\hline KIMIA KLINIK & 10 & & & $60-100 \mathrm{mg} / \mathrm{dL}$ \\
\hline GDA & 328 & & & $60-100 \mathrm{mg} / \mathrm{dL}$ \\
\hline GDP & & 370 & & \\
\hline GD2JpP & & & & \\
\hline
\end{tabular}




\begin{tabular}{|c|c|c|c|}
\hline IMUNOLOG & & & \\
\hline C-Peptide & & 2,74 & $1,1-4,4 \mathrm{ng} / \mathrm{mL}$ \\
\hline$\underline{\text { URINALISIS }}$ & & & \\
\hline Wama & Kuning & & Kuning \\
\hline$\underline{\text { Kejernihan }}$ & Jernih & & Jernih \\
\hline $\mathrm{Ph}$ & 6,0 & & $5-6,5$ \\
\hline Berat Jenis & 1,025 & & $1,015-1,025$ \\
\hline$\underline{\text { Lekosit }}$ & Negatif & & Negatif \\
\hline Nitrit & Negatif & & Negatif \\
\hline$\underline{\text { Urobilin }}$ & Negatif & & Negatif \\
\hline$\underline{\text { Protein }}$ & Negatif & & Negatif \\
\hline Eritrosit & Trace & & Negatif \\
\hline$\underline{\text { Keton }}$ & +1 & & Negatif \\
\hline Bilirubin & Negatif & & Negatif \\
\hline Glukosa & +3 & & Negatif \\
\hline$\underline{\text { Silinder }}$ & Negatif & & Negatif \\
\hline Lekosit & $3-6$ & & $0-3$ lbp \\
\hline$\underline{\text { Eumorfik }}$ & $100 \%$ & & $\%$ \\
\hline$\underline{\text { Dismorfik }}$ & $0 \%$ & & $\%$ \\
\hline Bakteri & +1 , batang & & Negatif \\
\hline$\underline{\text { Kristal }}$ & Negatif & & Negatif \\
\hline Epitel & +1 gepeng & & Negatif \\
\hline
\end{tabular}

\section{Diagnosa Klinis}

Diabetes melitus tipe-1, DD. Maturity onset diabetes of the young (MODY)

\section{Penatalaksanaan}

Pada pasien diberikan terapi :

- IVFD $\mathrm{NaCl} 0,9 \%$

- Inj. S.C Noverapid 4-4-3-0
Inj. S.C Lovemir 0-0-0-3

Diit DM 1900 kcal

\section{PEMBAHASAN}

Diabetes mellitus (DM) tipe-1 adalah DM akibat insulin tidak cukup diproduksi oleh sel beta pankreas, sehingga terjadi hiperglikemia (WHO, 
2017). Tipe -1 ini ditandai dengan berkurangnya sel beta pankreas yang diperantarai oleh imun atau antibodi, sehinga sepanjang hidup penderita ini tergantung pada insulin eksogen (Chiang JL, 2014). Gejala klinik khas yang dapat ditemukan sebagai akibat kurangnya insulin : poliuri, polidipsi, berkurangnya berat badan, dan hiperglikemia yang tidak berespons terhadap obat diabetik oral. Pada anak-anak, sering kali ditemukan gejala yang akut dan berat dari poliuri, polidipsi, dan ketonemi. Sedangkan pada dewasa tipe-1 berjalan lebih lama dan perlahan dengan presentasi klinis pada awalnya menyerupai DM tipe-2 (Chiang JL, 2014).

Marker sistem imun pada destruksi sel beta ini terdiri dari autoantibodi sel pulau langerhans, autoantibodi insulin, autoantibodi GAD65 serta autoantibodi tirosin posfatase IA-2 dan IA-2 beta. Satu atau lebih dari autoantibodi tersebut ditemukan pada $85-90 \%$ saat kondisi hiperglikemia puasa terdeteksi. DM tipe 1 juga berkaitan erat dengan HLA yang tersambung dengan gen DQA dan DQB .dan juga dipengaruhi oleh gen DRB (ADA, 2012). Pada DM tipe 1 proses destruksi sel beta bervariasi, dapat timbul cepat(saat anak-anak dan remaja) yang merupakan paling umum terjadi, namun juga dapat terjadi lambat (saat dewasa) (Khan SA, 2017).

Pemeriksaan laboratorium yang sensitif dapat mendeteksi $98 \%$ pasien dengan autoantibodi saat diagnosis. Namun demikian banyak laboratorium komersial yang tidak mempunyai sensitifitas dan spesifitas yang baik untuk pemeriksaan kelima autoantibodi : GADA, islat cell antibodies (ICA), insulin autoantibodies (IAA), protein tyrosine phosphat antibodies, dan zinc transporter protein. Sehingga kurang tepat bila melaporkan pasien dengan antibodi negatif. Kemungkinan negatif palsu lainnya adalah kadar autoantibodi yang rendah. Disamping itu pada etnis tertentu seperti Asian, sering kali autoantibodinya negatif (Chiang JL, 2014).

Mekanisme autoimun pada DM tipe 1 dapat dipicu oleh adanya infeksi atau stimulus lingkungan lain seperti yang telah dipaparkan sebelumnya. Sel beta dapat mulai berkurang jumlahnya dan sekresi insulin menurun secara progresif meskipun kadar gula darah masih dapat dipertahankan. Hal ini terjadi karena gambaran diabetes tidak akan terlihat sampai $80 \%$ sel beta rusak. Namun, pada saat kebutuhan insulin meningkat (masa pubertas dan infeksi), proses destruksi yang terus-menerus berlanjut mengakibatkan jumlah insulin semakin sedikit dan tidak cukup untuk memenuhi kebutuhan sehingga gejala DM terlihat (Powers CA, 2017).

Kerusakan sel beta yang progresif merupakan petanda penting pada tipe-1, namun residual C-peptida dapat terdeteksi lebih dari 40 tahun setelah diagnosis, baik diagnosis awal ditemukan saat masa kanak-kanak, maupun saat dewasa (Davis et al, 2015). Davis melaporkan pada penderita DM Tipe-1 terdapat 29\% terdeteksi non-fasting C-Peptide yang akan menurun saat terdiagnosis (Davis AS, 2012).

DM tipe 1 di atas bersifat poligenik. Terdapat tipe lain yang bersifat monogenik dan jarang terjadi yaitu Maturity onset diabetes of the young (MODY). MODY adalah kelompok Diabetes mellitus (DM) keturunan yang berbeda dari DM tipe-1 (insulin-dependent) dan tipe-2 (noninsulindependent). MODY lebih bersifat familial noninsilin dependent diabetes, dan lebih sering terdiagnosis sebelum usia 25 tahun. Patofisiologi DM tipe ini adalah mutasi genetik yang menyebabkan disfungsi sel beta pankreas. Manifestasi klinik pada pasien MODY sangat heterogen tergantung dari etiologi genetiknya (Gardner DSL, 2012).

MODY ditegakkan dengan pemeriksaan diagnosis molekuler. Hingga saat ini, sudah ditemukan 40 jenis subtipe diabetes monogenik, masing-masing memiliki fenotipe tersendiri dengan pola pewarisan spesifik. ${ }^{6}$ Mutasi yang tersering adalah mutasi pada glucokinase (GCK) (MODY 2) dan hepatocyte nuclear factor (HNF)1A/4A (MODY 3 and MODY 1). Mutasi GCK menyebabkan hiperglikemia yang ringan, asimptomatik, dan hiperglikemia puasa yang stabil, sehingga tidak membutuhkan terapi spesifik. Namun, mutasi pada HNF1A and HNF4A menyebabkan disfungsi sel beta pankreas yang progresif dan hiperglikemia, yang dapat mengakibatkan komplikasi mikrovaskule (Anik, A, 2015).

Pasien MODY sering kali mempunyai satu atau lebih manifestasi berikut : riwayat keluarga dengan semua tipe DM, tidak tergantung insulin, tidak mempunyai autoantibodi terhadap antigen pankreas, dan terdapat produksi insulin endogen (terdeteksi C-peptide, hanya perlu sedikit insulin), 
dan jarang mengalami ketoasidosis (Gardner DSL, 2012).

Pada pasien anak ini, terdapat keluhan khas diabetik yaitu poliurin yang disertai kelemahan badan. Riwat penyakit keluarga, ditemukan bahwa kakek pasien menderita DM. Berat badan anak dalam batas normal. Glukosa darah selalu tinggi, dan saat diperiksa di laboratorium rumah sakit juga menunjukkan hiperglikemia acak, puasa, dan 2 jam post prandial. Pada awalnya pasien diduga menderita DM-tipe 1, oleh karena pada anak tipe tersering adalah tipe-1. Kemudian dilakukan pemeriksaan Cpeptida dengan hasil masih dalam rentang normal yaitu 2,74 ng/ml. Pada DM tipe 1 tersering kadar $C$ peptide sangat rendah oleh akibat sel beta pankreas yang rusak tidak mampu untuk memproduksi insulin. Davis melaporkan terdapat 29\% pasien DM tipe 1 yang masih terdeteksi kadar C-peptida nya saat terdiagnosis, yang dalam perjalanan penyakitnya akan menurun. ${ }^{9}$ Namun demikian oleh karena kadar C-peptida nya yang normal tersebut perlu dipertimbangkan diagnosis banding lainnya yaitu MODY. Pada pasien MODY sering kali kadar Cpeptida masih normal. pada DM tipe 1 maupun MODY hubungan familial sangat kuat. Pada pasien ini kakeknya menderita DM. Penetapan diagnosis pasti yang disarankanpada pada pasien ini adalah pemeriksaan : autoantibodi pankreas, dan pemeriksaan genetik.

\section{SIMPULAN}

Telah dilaporkan seorang anak perempuan berusia 9 tahun dengan hiperglikemia dan kadar C peptida yang normal, didiagnosis Diabetes melitus tipe-1, diferential dignosis Maturity onset diabetes of the young (MODY).Penegakkan diagnosis pasti yang disarankanpada pada pasien ini adalah pemeriksaan : autoantibodi pankreas, dan pemeriksaan genetik.

\section{DAFTAR PUSTAKA}

Anik A, Catli G, Abaci A, et al, Maturity-onset diabetes of the young (MODY): an update, J.pediatr Endocrinol Metab, 2015, 28 ; 3-4

Chiang JL, Kirkman MS, Laffel LMB, et al, Type 1 Diabetes Through the Life Span: A Position Statement of the American Diabetes
Association, 2014, $\quad \underline{\text { http:// }}$ care.diabetesjournals.org/content/37/7/2034

Davis AS, Dubose SN, Haller MJ, Prevalence of Detectable C-Peptide According to Age at Diagnosis and Duration of Type 1 Diabetes, 2012; http://care.diabetesjournals.org/ content $/ 38 / 3 / 476$

Gardner DSL, Tai ES, Clinical features and treatment of maturity onset diabetes of the young (MODY), Diabetes Metab Syndr Obes. 2012; 5: 101-108

Imagawa A, Hanafusa T, Miyagawa JI, Matsuzawa Y. A Novel subtype of type 1 diabetes mellitus characterized by a rapid onset and an absence of diabetes-related antibodies. N Engl J Med, 2000;342(5):301-7

Khan SA. Guidelines-What's New. Classiûcation and Diagnosis of Diabetes. ADA 2017;39(Suppl.1):S13-S22

Ozougwu JC, Obimba KC, Belonwu CD, Unakalamba CB. The pathogenesis and pathophysiology of type 1 and type 2 diabetes mellitus. Akademic Journal 2013; 4(4): 46-57

Powers CA. Diabetes Mellitus in Horrison's Principles Of Internal Medicine. Chapter 344;1;18 . Available from http:// accessmedicine.mhmedical.com/ content.aspx?bookid $=331 \&$ sectionid $=40727149$ (Cited on Jan1 ${ }^{\text {st }}$ 2017)

Tengguna L. Diabetes Monogenik pada Anak. CDK-248/vol.44 no1, 2017

WHO, Diabtes mellitus, Media Centre, 2017, http:/ Lwww.who.int/mediacentre/factsheets / fs312/en/ 